To cite this article: Lazarus C. Njoku \& Eucharia Ken-Agbiriogu (2021) Awareness and Use of Cloud Computing: Its Implications in Selected Academic Libraries in Imo State, Nigeria. Information Impact: Journal of Information and Knowledge Management, 12:1, 62-75, DOI: 5https://dx.doi.org/10.4314/iijikm.v12i1.5

To link to this article: https://dx.doi.org/10.4314/iijikm.v12i1.5

\title{
Awareness and Use of Cloud Computing: Its Implications in Selected Academic Libraries in Imo State, Nigeria
}

\author{
${ }^{1}$ Lazarus C. Njoku \\ ${ }^{1}$ Eucharia Ken-Agbiriogu \\ ${ }^{1}$ Department of Library and Information Science, Imo State University, Owerri, Nigeria
}

\begin{abstract}
The study investigated awareness and use of cloud computing; its implications by libraries in selected academic libraries in Imo State, Nigeria. Four research questions were asked and answered. Also, three hypotheses were formulated and tested at 0.05 significance level. Survey research design was adopted. The total population of the study was 53 librarians, comprising professional staff of the library in Imo State University, Owerri, Federal Polytechnic, Nekede and Alvan Ikoku Federal College of Education, Owerri. The sample size was the entire population; hence the census enumeration sampling technique was employed. Rating scale was used for data collection. Data collected were presented in tables and column charts, and analyzed using mean, standard deviation. Testing of hypotheses was done using F-ratio (ANOVA) at the significance level of 0.05 . Findings reveal that there is certain level of awareness on cloud computing technologies and models in the libraries studied. It was also discovered that cloud computing technology were used by libraries in the institutions studied, and economy of resource cost effectiveness and file sharing are some of the major positive implications of librarians adoption cloud computing technologies. However security and privacy, multiple taxation were also identified as major negative implications of cloud computing adoption by the librarians in discharging their functions in the libraries. Based on these findings, recommendations were made.
\end{abstract}

Keywords Cloud Computing, Librarians, Awareness, Use, Implication

CONTACT Lazarus C. Njoku and Eucharia Ken-Agbiriogu lazarus_njoku@yahoo.com Department of Library and Information Science, Imo State University, Nigeria. 


\section{Introduction}

The exponential growth and development of Information Technology (IT) has brought a tremendous change in virtually all areas of human sector. In today's information society, everything is changing in seconds and growing at geometric speed rate, especially in the area of web-based technologies. Consequently, every human being, particularly staff of organizations, including that of the library is struggling to keep abreast of the latest development in the Information Technology (IT). This leads to the benefits of cloud computing in organizations, including the library. The emergence of cloud computing and adoptability in the service of academic library is one of the alternative bail out for libraries to incorporate and wine back the hearts of their users. The cloud computing applicability to library serves as librarians' progressive response to a changing information environment and need to maintain their relevance in today's dynamic information driven society.

In the library, due to its dynamic, flexibility, replaceable and ease of use nature, cloud computing has become more adoptive in helping the library to keep and maintain record of data, rendering efficient services. Suman and Singh (2016) stated the benefits of cloud computing to library is that it enhances easy access to data over the internet, promotes accessibility to file sharing and savings, reduction of cost in managing and maintaining IT system, collaboration of projects being cost effective etc. Amidst all the benefits prevailed in adopting cloud computing technology by librarians in discharging their functions in the history, there are also many challenges facing it. They include: security and privacy, application migration from one cloud to other; interoperability, computing performance, reliability and availability (Mate 2016).

Cloud computing is an evolving paradigm that offers opportunities to library users or group of users that need to be provided limitless and without time, location bound services. However, in spite of great work advantages, many librarians still pay levity to its full awareness and adoptability to their service operation. One begins to wonder the cause and questions its level of awareness and use by librarians in academic library. Against this backdrop, the researcher investigates the awareness and use of cloud computing, its implications in selected libraries in Imo State Nigeria.

\section{Purpose of the study}

The general purpose of this study is to investigate the awareness and use of cloud computing: its implications by libraries in selected academic libraries in Imo State, Nigeria, specifically, this study seeks to:

1. To determine the extent of awareness of cloud computing technologies among the librarians in Imo State University, Owerri, Federal Polytechnic, Nekede and Alvan Ikoku Federal College of Education, Owerri.

2. To assess the extent of awareness of cloud computing services models among the libraries in the libraries studied. 
3. To find out the extent of use of cloud computing technologies among libraries in the libraries studied.

4. To identify the extent of implications on cloud computing technologies adoption by librarians in their operation services in the libraries studied.

\section{Research questions}

In line with the above stated objectives, the following research questions are posed:

1. To what extent do the mean perception scores of respondents differ on awareness of cloud computing technologies in Imo State University, Owerri, Federal Polytechnic, Nekede and Alvan Ikoku Federal College of Education, Owerri?

2. To what extent do the libraries studied differ in mean perception scores of respondents on awareness of cloud computing services model?

3. To what extent do the mean perception scores of respondents differ on use of cloud computing technologies in the libraries studied?

4. To what extent do the libraries studied differ in mean perception scores of respondents on implication of cloud computing in their operation services in the libraries studied.

\section{Hypotheses}

The following null hypotheses were formulated and tested at 0.05 significance level.

(1) $\mathrm{HO}_{1}$ : The mean perception scores of respondents on the extent of awareness of cloud computing technologies in the libraries studied does not differ significantly.

(2) $\mathbf{H O}_{2}$ : There are no significantly among the mean perception scores of respondents on extent of awareness of cloud computing models services in the libraries studied.

(3) $\mathrm{HO}_{3}$ : The mean perception scores of respondents on extent of use of cloud computing technologies in the libraries studied does not differ significantly.

\section{Review of literature}

Academic libraries are those libraries situated in institutions of higher learning such as universities, polytechnics, colleges of education, college of technology which are designed and geared towards the achievement of educational objectives of the parent institutions (Agu, 2014). Academic libraries are referred to as the heart or nerve centres of institutions of higher learning; this implies that all academic activities revolve around the libraries.

Cloud computing is an emerging trend that has greatly affected the services operations of organizations, including that of libraries. Meanwhile, cloud computing means cloud based networking environment that provides services remotely over the internet. Swapna and Birader (2017) described that in cloud computing, the word 'cloud' is used as metaphor for the internet, based on the standardized use of a cloud-like shape to denote a network on telephony schematics. The 'cloud' element of cloud computing can be seen as an acronym that stands for c-computing resources; L- 
location independent; O-can be accessed via online means; U-used as utility and P-is available on demand.

Besides, Rena (2010) defined cloud computing as a pool of abstracted highly scalable and managed computer infrastructure capable of hosting end-customer applications and billed by consumption. National Institute of Standard and Technology (NIST) in Mell and Grance (2011) defines cloud computing as a model for enabling ubiquitous, convenient, on-demand network access to shared pool of configurable computing resources (for example, network, server, storage, applications and services). Cloud computing requires remote server as well as internet to maintain and organize data and application. Suciu et al (2013) conceptualized, cloud computing as the delivery of computing and storage capacity as service to a community of end-users. They also reiterated that cloud computing also extends the concept of IT services by combining user data, software and ondemand computation resources over a network.

\section{Types of Cloud Computing}

Many scholars have categorized cloud computing in different types. Swapna and Birader (2017) clearly stated the types of cloud computing as: on-the-basis of services and on-the-basis of usage. He further explained that on-the-basis of services includes infrastructure platform, services while on-the-basis of usage, it includes private clouds, public clouds, hybrid clouds, community clouds and special clouds. Dahunsi and Owoseni (2015), describes the typology of cloud computing as service infrastructure as a service (Iaas), platform as a service (Paas) and software as a service (Saas). He further describes identified from cloud architectural solution as deployment models; private cloud, community cloud, public cloud and hybrid cloud. Infrastructure as service (Iaas) is providing consumer with computing resources such as computations, storage, networks, and allow the consumer to deploy and run arbitrary software which include operating system and application. Notable commercial solution of (Iaas) are Amazon cloud, Rackspace cloud and Gohrid.

* Platform as services (Paas). These are set of applications developed by the services provider to use cloud infrastructure and example Google DOS (Swapana and Birader, 2017).

* Software as service (Saas). This provides consumer with the capability to use the provider's application running on a cloud infrastructure. It is a delivery model in which software and associated are centrally hosted on the cloud. All these are major service models which are prominently used to run cloud computing (Dahunsi and Owoseni, 2015).

On the bases of Deployment Models, it is being explained briefly by Wada (2016) in four basic categories: private, public, community and hybrid deployment models. Private cloud, Arokia et al (2012) explained that private cloud or model is based upon a pool of shared resources, whose access is limited with organizational boundaries. Sucin et al (2013) stated that private cloud is a kind of cloud infrastructure that is provisioned for exclusive use by a single comprising multiple 
consumers (for example, business units), public cloud. Any institute may use cloud service from third party which may available free or with cost can be considered as public cloud. For example, Google apps, windows, Azure (Swapana and Birader, 2017).

Still on Deployment Models, Suciu et al (2013) stated that community model or cloud as the types that is being shared between the organizations with similar interests and requirements whether managed internationally or by the third-party and hosted internally or externally.

* Hybrid cloud: Quahabi et al (2014) explained that cloud infrastructure is a composition of two or more distinct cloud infrastructures (private, community, public) that remain unique entitle, but are bound together by standardizing or proprietary technology that enable data and application portability (for example, cloud bushing for load balancing between clouds).

Figure I: Types of cloud computing (Adopted from Swapna and Birader Model

The above review can be summed into diagrammatic model as shown below:

\section{Types of Cloud Computing}

On the basis of services

- Infrastructure

- Platform

- services
On the basis of usage

- Private clouds

- Public clouds

- Hybrid clouds

- Community clouds

- Special clouds

\section{Benefits of Cloud Computing in Academic Libraries}

Cloud computing has significant impact on the services of any organization. Mate (2016) stated the advantages of cloud computing as cost efficiency. Cloud computing is the most cost efficient method to use, maintain and upgrade as explained. He further said that cloud computing is advantageous to libraries because of its information, automatic software integration and quick deployment. Kendrick (2014) observed that some libraries have jumped and are increasingly stepping into the realm of digital librarianship as well as platforms that extend information technology obtainable capabilities, and thus at length depends on using the cloud facilities. Agu (2014) in Romero (2012) is the ability of reuse, economy of resources and maximization of utilities through reduced cost associated with wastes of resources. Yuvarej (2013) enlisted some benefits of cloud computing to librarians to include high computing power, location and device independency, high scalability, less 
maintenance, less indulgence, unlimited storage capacity, diverse support, faster deployment, etc with cloud computing optimization of resources and services are ensured in libraries. These benefits have positive implication to library services and growths.

However, cloud computing has negative implication in application to the library operation. Most librarians are dread of its usage as the reality of its inherent challenges. According to Nazir (2013) posited that in spite of cloud computing usage, there are certain aspects associated with cloud computing, certain loopholes in its architecture have made cloud computing vulnerable to various securities and privacy threats. Another implication of applying cloud computing is that internet penetration in Nigeria is very poor due to inadequacy of infrastructure. Census Burea (2014) suggests that internet penetration in Nigeria is 33 percent. Multiple taxation on the part of the federal, state and local government as well as weak regulation, etc, also created negative implication on cloud computing adoption by organizations in Nigeria (Nazir, 2013). Cloud computing has not yet been made possible for every organization to easily repose confidence on its reliability and portability hence, application can easily be migrated from one cloud to another in different standard languages.

\section{Methodology}

This study adopted survey design. The total population of the study is 53, comprising of 15,13 and 25 professional staff of the library in Imo State University, Owerri, Federal Polytechnic Nekede and Alvan Ikoku Federal College of Education, Owerri, respectively. The sample was the entire population of the study hence census enumeration sample technique was employed owing to the fact that the population figure is very small and accessible. An instrument for data collection was rating scale developed in four-points likert format, it was rated using Highly Aware (HA), Fairly Aware (FA), Poorly Aware (PA), and Not Aware (NA); Strongly Agree (SA), Agree (A), Disagree (A), and Not Agree (NA). The research questions were answered using mean and standard deviation. For clear presentation of the analysis, questions 1 and 3 were done in tables while questions 2 and 4 were done in column charts. Besides, the study used the following scale for decision on research question conclusion: $3.50-4.00=\mathrm{HA}, 2.50-3.49=\mathrm{FA}, 1.50-2.49=\mathrm{PA}$, and 1.00-1.49 = NA; 3.50-4.00 = SA, 2.50-3.49= A, 1.50-2.49 = D and 1.00-1.49= S.D. The test of significance for the hypothesis was done at 0.05 level using F-ratio (ANOVA).

\section{Presentation of results}

Table 1: Mean perception score of Respondents on Extent of Awareness on Cloud Computing Technologies

\begin{tabular}{|c|c|c|c|c|c|c|c|c|c|c|c|}
\hline \multirow[b]{2}{*}{$S / N$} & \multirow[b]{2}{*}{ QUESTION ITEMS } & \multicolumn{3}{|c|}{ University Staff } & \multicolumn{3}{|c|}{ Polytechnic Staff } & \multicolumn{3}{|c|}{$\begin{array}{l}\text { College of Edu. } \\
\text { Staff }\end{array}$} & \multirow[b]{2}{*}{ Decision } \\
\hline & & $\mathbf{N}$ & $\overline{\boldsymbol{X}}$ & SD & $\mathbf{N}$ & $\overline{\boldsymbol{X}}$ & SD & $\mathbf{N}$ & $\overline{\boldsymbol{X}}$ & SD & \\
\hline 1. & $\begin{array}{l}\text { Hotmail or window live } \\
\text { mail }\end{array}$ & 15 & 3.99 & 0.54 & 13 & 3.46 & 0.78 & $\begin{array}{l}2 \\
5\end{array}$ & 3.40 & 0.87 & $\begin{array}{l}\text { Highly } \\
\text { Aware }\end{array}$ \\
\hline 2. & Facebook & & 3.77 & 0.96 & & 3.46 & 0.66 & & 3.72 & 0.61 & Highly \\
\hline
\end{tabular}




\begin{tabular}{|l|l|l|l|l|l|l|l|l|l|l|l|}
\hline & & & & & & & & & & & Aware \\
\hline 3. & Dropbox & & 3.33 & 1.11 & & 3.46 & 0.66 & & 3.36 & 0.99 & $\begin{array}{l}\text { Fairly } \\
\text { Aware }\end{array}$ \\
\hline 4. & YouTube & & 3.67 & 0.50 & & 3.38 & 0.96 & & 3.36 & 0.91 & $\begin{array}{l}\text { Fairly } \\
\text { Aware }\end{array}$ \\
\hline 5. & $\begin{array}{l}\text { Google Apps (Gmail, } \\
\text { Google Doc) }\end{array}$ & & 3.83 & 0.72 & & 3.31 & 0.86 & & 3.80 & 0.65 & $\begin{array}{l}\text { Fairly } \\
\text { Aware }\end{array}$ \\
\hline & Grand Mean & & $\mathbf{3 . 7 2}$ & & & $\mathbf{3 . 4 1}$ & & & $\mathbf{3 . 5 3}$ & & \\
\hline
\end{tabular}

Table 1 shows the mean perception scores of the respondents on extent of currencies on cloud computing Technology. It was revealed the grand mean of 3.72 for IMSU, 3.41 for POLYNEK and 3.53 for AIFCE. The results show that librarians from IMSU and AIFCE were highly aware of cloud computing technologies while that of POLYNEK fairly aware of the cloud computing technologies.

Figure 2: Column chart showing the Mean Perception Score of Respondents on Extent of aware of cloud computing services models.

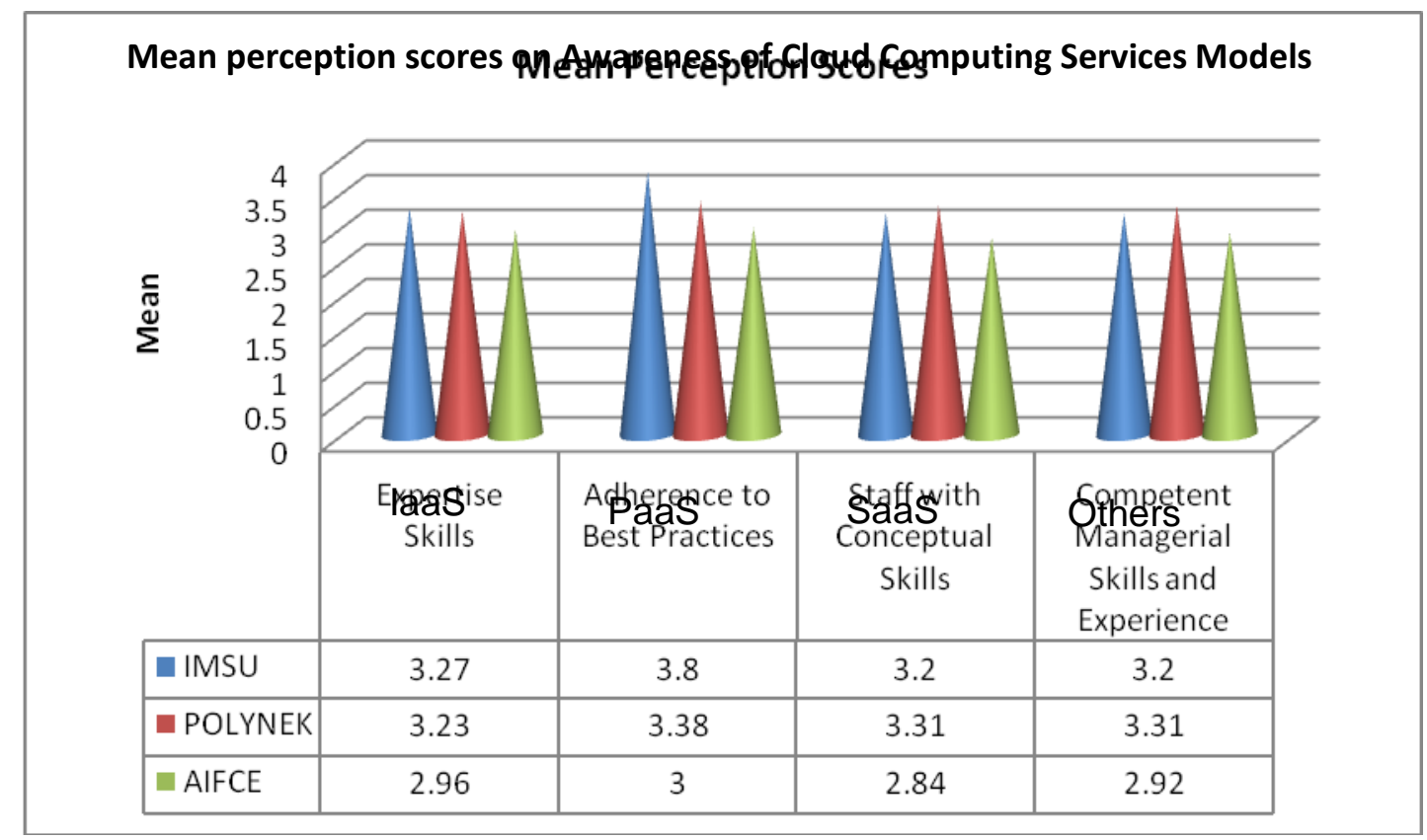

Figure 2 shows the mean perception scores of the respondents on the extent of awareness on cloud computing services models. The result reveals the grand mean of 3.37 for IMSU, 3.31 for POLYNEK and 2.93 for AIFCE. This shows that librarians from IMSU, POLYNEK and AIFCE were fairly aware of the existence of cloud computing services models. 
Table 2: Mean perception scores of respondents on Extent of use of cloud computing technologies

\begin{tabular}{|c|c|c|c|c|c|c|c|c|c|c|c|}
\hline \multicolumn{2}{|c|}{ QUESTION ITEMS } & \multicolumn{3}{|c|}{ University Staff } & \multicolumn{3}{|c|}{ Polytechnic Staff } & \multicolumn{3}{|c|}{$\begin{array}{l}\text { College of Edu. } \\
\text { Staff }\end{array}$} & \multirow[b]{2}{*}{ Decision } \\
\hline $\mathbf{S} / \mathbf{N}$ & & $\mathbf{N}$ & $\overline{\boldsymbol{X}}$ & SD & $\mathbf{N}$ & $\overline{\boldsymbol{X}}$ & SD & $\mathbf{N}$ & $\overline{\boldsymbol{X}}$ & SD & \\
\hline 1. & $\begin{array}{l}\text { I Do Often Use } \\
\text { YouTube to access } \\
\text { current movie and } \\
\text { pictures }\end{array}$ & 15 & 3.20 & 0.94 & 13 & 3.54 & 0.66 & 25 & 3.48 & 0.82 & Agree \\
\hline 2. & $\begin{array}{l}\text { I hardly make use } \\
\text { of Dropbox }\end{array}$ & & 3.27 & 0.96 & & 3.46 & 0.78 & & 3.24 & 1.01 & Agree \\
\hline 3. & $\begin{array}{l}\text { I do browse through } \\
\text { facebook every day } \\
\text { to enrich my social } \\
\text { life }\end{array}$ & & 3.27 & 0.88 & & 3.38 & 0.87 & & 3.48 & 0.92 & Agree \\
\hline 4. & $\begin{array}{l}\text { Hotmail or window } \\
\text { live mail has help } \\
\text { me a lot saving } \\
\text { time and exost }\end{array}$ & & 3.27 & 0.88 & & 3.38 & 0.65 & & 3.44 & 0.96 & Agree \\
\hline 5. & $\begin{array}{l}\text { Google App (Gmail, } \\
\text { Google D.C) is } \\
\text { highly used by } \\
\text { respncherum and } \\
\text { effective. }\end{array}$ & & 3.27 & 0.88 & & 3.23 & 0.93 & & 3.28 & 1.06 & Agree \\
\hline & Grand Mean & & 3.26 & & & 3.39 & & & 3.38 & & Agree \\
\hline
\end{tabular}

Table 2 shows the mean perception scores of the respondents on the extent of use of cloud computing technologies. It was revealed that the librarians from IMSU, POLYNEK and AIFCE agreed on the extent of use of YouTube, dropbox, facebook, Hotmail, Google App etc for access information and enrich their social life as well as seeking solution to research problems. This is evident as the grand means of IMSU indicates 3.26, POLYNEK 3.39 and AITCE 3.38.

Figure 3A: Column chart showing the mean perception scores of respondents on Extent of positive implications of cloud computing adoption by librarians in discharging their professional functions.

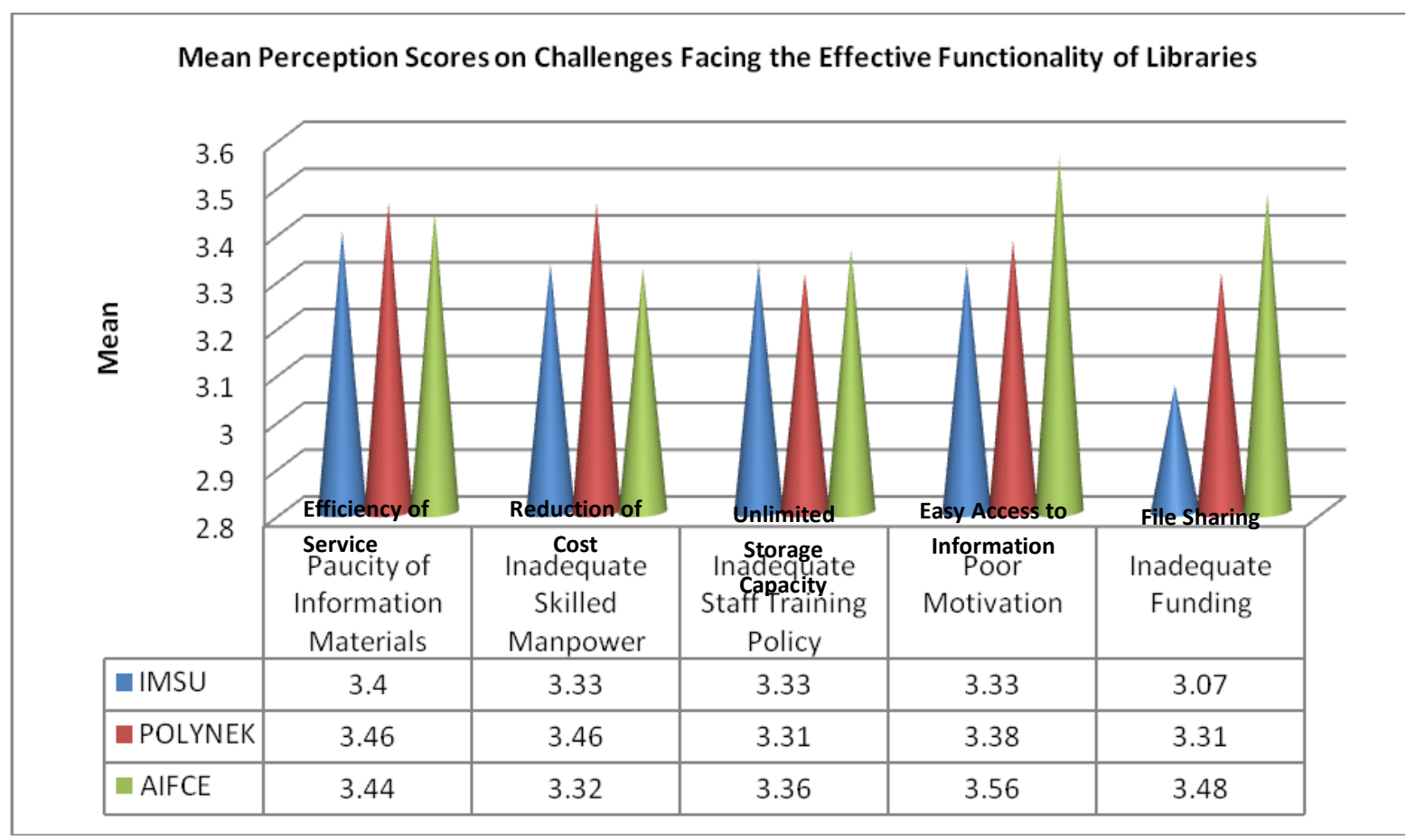


Figure $3 \mathrm{~A}$ shows the mean perception scores of the respondents on the positive implications of cloud computing adoption by librarians in discharging their professional services in the library; it was revealed the grand mean of 3.29 for IMSU, 3.38 for POLYNEK and 3.43 for AIFCE. The results show that the librarians from these institutions studied agree cloud computing has positive affected their professional services in terms of efficiency of services, reduction of cost, unlimited storage capacity essay access to information and file sharing.

Figure 3B: Mean perception scores of respondents on Extent of Negative Implication of cloud computing adoption by libraries in discharging their professional services.

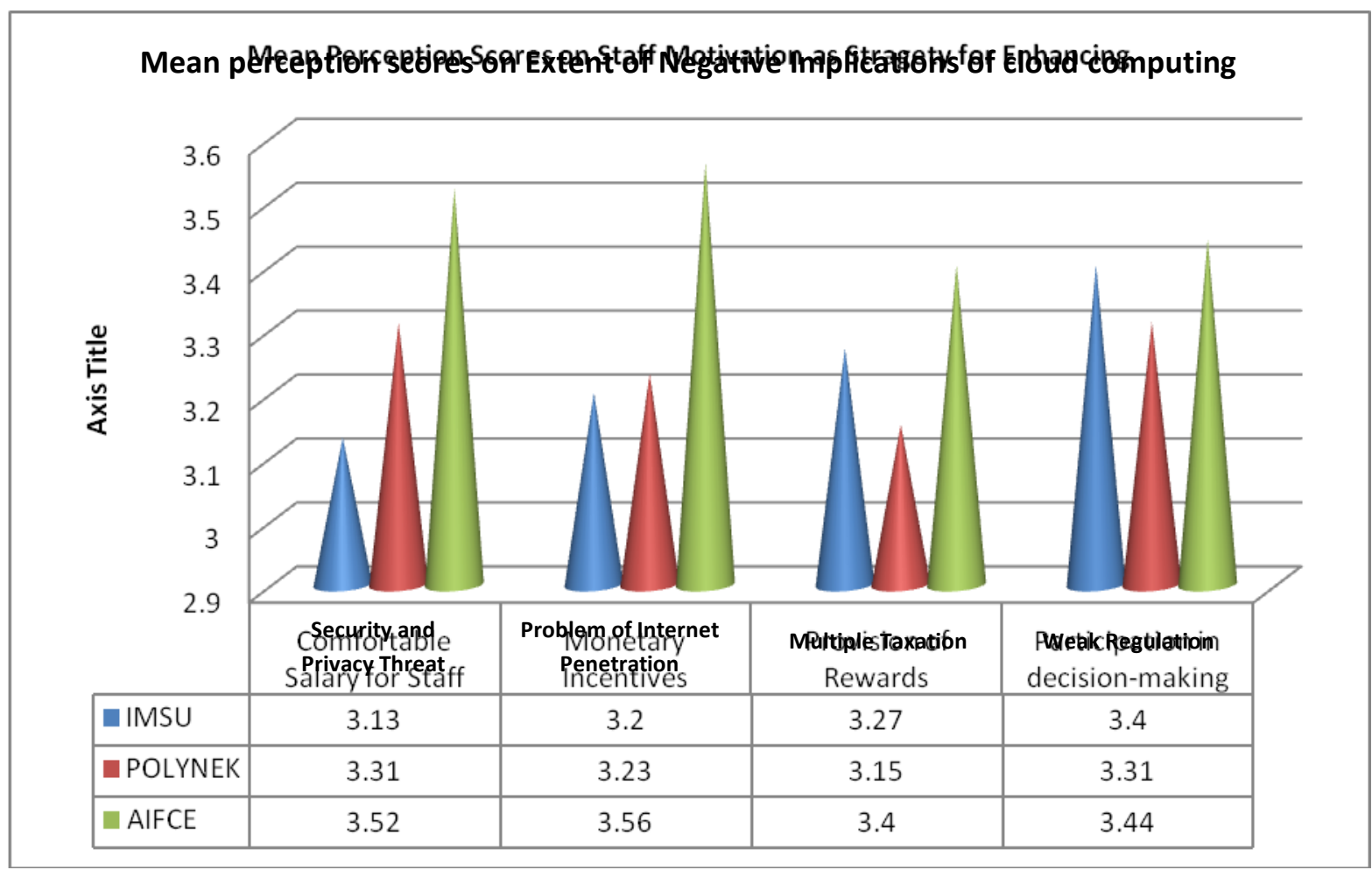

Figure 3B shows the mean perception scores of respondents on the extent of negative implication of cloud computing adoption by librarians in discharging then professional services. The grand mean of the respondent in the institutions studied revealed 3.25 for IMSU, 3.25 for POLYNEK and 3.48 for AIFCE. This shows that the librarians experience challenges and hurdles in the course of using this cloud computing to discharge their professional function in the library. The implication is that it privacy, internet penetration, multiple taxation etc constitute $\operatorname{cog}$ on the wheel of effective professional services delivery by the librarians. 


\section{Test of hypotheses}

The following null hypotheses were formulated and tested at 0.05 level of significance;

\section{Hypothesis One}

Table 3: One-way ANOVA Summary Table Showing Response on the Extent of Awareness of Cloud Computing Technologies

\begin{tabular}{|l|r|r|r|r|l|l|l|}
\hline $\begin{array}{l}\text { Sources of } \\
\text { variation }\end{array}$ & $\begin{array}{l}\text { Sum } \\
\text { Squares }\end{array}$ & df & $\begin{array}{l}\text { Mean } \\
\text { Square }\end{array}$ & F-ratio & Sig. & F-tab & Decision \\
\hline Between Groups & 872.550 & 3 & 290.850 & 2.739 & 0.520 & 2.76 & Accept \\
\hline Within Groups & 1699.200 & 16 & 106.200 & & & & \\
\hline Total & $\mathbf{2 5 7 1 . 7 5 0}$ & $\mathbf{1 9}$ & & & & & \\
\hline
\end{tabular}

Decision Rule: Since the F-cal is less than the F-table at 5\% level, we accept the null hypothesis and conclude that there is no significant difference among the mean perception scores on extent of awareness of cloud computing technologies in the institutions studied.

\section{Hypothesis Two}

Table 4: ANOVA Summary Table Showing response on extent of awareness of cloud computing service models

\begin{tabular}{|l|r|r|r|r|r|r|r|}
\hline $\begin{array}{l}\text { Sources of } \\
\text { Variation }\end{array}$ & \multicolumn{1}{|c|}{$\begin{array}{c}\text { Sum of } \\
\text { Squares }\end{array}$} & \multicolumn{1}{c|}{ df } & $\begin{array}{c}\text { Mean } \\
\text { Square }\end{array}$ & F-ratio & Sig. & F-tab & Decision \\
\hline Between Groups & 214.500 & 3 & 71.500 & 1.623 & .879 & 2.76 & Accept \\
\hline Within Groups & 528.500 & 12 & 44.042 & & & & \\
\hline Total & $\mathbf{7 4 3 . 0 0 0}$ & $\mathbf{1 5}$ & & & & & \\
\hline
\end{tabular}

Decision Rule: Since the F-cal is less than the F-table at 5\% level, we accept the null hypothesis and conclude that there is no significant difference among the institutions studied in the mean perception scores on extent of awareness on cloud computing service models.

\section{Hypothesis Three}

Table 5: ANOVA Summary Table Showing response on Extent of Use of Cloud Computing Technologies

\begin{tabular}{|l|r|r|r|r|r|r|r|}
\hline $\begin{array}{l}\text { Sources of } \\
\text { Variation }\end{array}$ & \multicolumn{1}{c|}{$\begin{array}{c}\text { Sum of } \\
\text { Squares }\end{array}$} & df & Mean Square & F & Sig. & F-tab & Decision \\
\hline Between Groups & 288.550 & 3 & 96.183 & 2.071 & 0.670 & 2.76 & Accept \\
\hline Within Groups & 743.200 & 16 & 46.450 & & & & \\
\hline Total & $\mathbf{1 0 3 1 . 7 5 0}$ & $\mathbf{1 9}$ & & & & & \\
\hline
\end{tabular}

Decision Rule: The F-cal is less than the F-table at 5\% level; therefore, we accept the null hypothesis and conclude that there is no significant difference among the institutions studied in the mean perception scores on extent of use of cloud computing technologies by the librarians. 


\section{Discussions of findings}

\section{Extent of Awareness of Cloud Computing Technologies}

The result of analysis in Tables 1 and 3 shows there is no significant difference on extent of awareness of cloud computing technologies among the librarians in these institutions studied. Librarians from IMSU and AIFCE affirmed highly extent of awareness on these technologies while that of POLYNELE affirmed fairly extent on awareness of these technologies. Meanwhile, it implies that the libraries from these institutions studied in any level awareness consideration are not unaware or alien to this new trend of technologies. This result corroborates with the finding of Rena (2010) in his empirical study at Kerala University library which revealed that $57.84 \%$ of library professional have certain level of awareness on cloud computing technologies.

\section{Extent of Awareness of Cloud Computing Service Models}

The results of analysis in figure 1 and Table 4 shows that there is no significant different on the awareness of cloud computing service models among librarians from the institutions studied. They were all fairly aware of the existence of cloud computing services models. This implies that they are keeping abreast of this cloud computing development. This finding is in line with that of Mavodza (2013) which revealed libraries and using software as a service (Saas), such as catalogue World cat, Google Dox; platform as a services (Paas) as in the use of Google engine, infrastructure as a services (Iaas) as in the use of D-space, FEDORA etc.

\section{Extent of Use of Cloud Computing Technologies}

Tables $2 \& 4$ report the result of data analysis in line with research question three and hypothesis three. Finding shows that there is no significant difference on use of cloud technologies by libraries from IMSU, POLYNEK and AIFCE. This is evident as they all agree on the extent of use cloud computing technologies such as Youtude, drop box, facebook, hot mail, Google App etc. This implies that they at their individual or office quarters enjoys these new trend of technologies to access information, enrich their social knowledge and skills as well as solving other academic challenges. This finding is in tandem with the views of Alhami and Khaparde (2014) and Mcmanus (2016) which stated that libraries and library professionals are shuffling their services with attachment in the use of cloud computing technologies networking with the facilities to access information anywhere and anytime, such technology are Twitter, facebook etc. Swapna and Birader (2017) also revealed that man library professionals accounts 3.9\% of Disagree of Dropbox, and have used other technologies line Gmail, facebook etc.

\section{Extent of Implications of Cloud Computing Technologies by the Librarians}

Figure $2 \mathrm{~A}$ shows the result of positive implications of cloud computing adoption by librarians in respect to their professional service operation. The finding shows that efficiency of service, reduction of cost, unlimited storage capacity, ease of access to information, file sharing etc are the positive 
implications of librarians' adoption of this technologies. This finding is similar to that of Agu (2014) in Remero (2012), stating that economy of resources, ability of reuse, reduction of cost and maximization of utilities are the positive implications of cloud computing in the library.

However, Table 2B shows the negative implications of cloud computing adoption by libraries in respect to their service operation. Security and privacy, multiple taxation, internet penetration etc are huddles towards using of these technologies in achieving a desired result by libraries in the library. This finding is in line with the view of Nuzir (2013) which stated that in spite of cloud computing usage, there are certain loopholes in its architecture which has made it vulnerable to security and privacy threat.

\section{Conclusion}

Cloud computing has become a welcome development among librarians and libraries. Its adequate integration in the library will tremendously transform the entire library system and ensure optimization of resources and users satisfaction therein. The role of every libraries is to render quality service with easy of use and build confidence of the library capacity in their users; this can only be achieved if they can reposition themselves to maximize the potentials of the cloud computing technologies.

\section{Recommendations}

The study puts forward recommendations based on the findings:

1. The library management is duty bound to sensitize their subordinates to abreast with the new trends in IT world. This can be done by way of encouraging them to embark on staff development problems on information technology field to enable them to be update their skills and knowledge and before better in the library.

2. The government of Nigeria should ensure there is adequate funding in our institutions of higher learning. This will enable the school administrators to equip their libraries very well and create enabling environment that promote professional growth in new technology adoption.

3. Libraries roles information driven economy can be made more functional if development policies are formulated and implemented adequately on the area of information technology. Libraries will be key into it and become more vibrant and efficient to their services.

4. For proper integration of cloud computing our libraries on libraries, electricity and ICT infrastructure are the backbone of library that poised to embrace this development. 


\section{References}

Agu, P.C. (2014). User and services of academic libraries. In F.C Ekere (ed). Administration of academic libraries: A book of reading (pp.120-128). Enugu: Praise House Publishers.

Alhamdi, F.A \& Khaparde, V. (2014). Collaboration in the computing among students of library and information science department of Babasasaheh Ambedkar Marathwada University, Aurangabad. International Journal of Advanced Library and information Science 2(12), 82 92. Retrieved from http: scientific cloud-journals.com/index.php.

Arokia, R., Rajan, P. and Shanmugapriyaa, S. (2012). Evolution cloud storage as cloud computing infrastructure service. IOSR J. comput. Eng. (IOSRJCE), 1(1), 38-45.

Dahunsi, F.M \& Owoseni, T.M. (2015). Cloud computing in Nigeria: The cloud ecosystem perspective. Nigerian Journal of Technology (NIJOTECH), 34(1), (pp 209-216).

Mate, S.K. (2016). Use of cloud computing in library services. International Journal of Engineering Science and Computing, 6(5), 4693.

Mavodza, J. (2013). The impact of cloud computing on the future of academic library practice and services. New Library World, $114 \quad$ (3/4), 132-141. Retrieved from http://www.emera/dinsight.com/journals.htm? Articleid =17084096.

Mcmanas, B. (2016). The implications of web 2.0 for academic libraries. Electron J. Acad. Special Libranianship 3(3), 1-10.

Mell, P. \& Grance, T. (2011). The NIST definition of cloud computing recommendations of the National Institute of Standards and Technology. Nist Special Pub. 145, 7.

Nazir, \& Rashis, S. (2013). Security threats with associated mitigation techniques in cloud computing. International Journal of Apple Information System (IJAIS), 5(7), 16-19.

Quahabi, S., (2014). Educational modeling computing IMS learning design. J Their Apple of Techno, 66(3), 654-660.

Rana, R. (2010). The future of cloud computing. Analysis, 1(1), 1-26.

Romero, N. (2012). Cloud computing in library automation: Benefits and drawbacks. The Botton Line: Manage. Library Finance, 25(3), 110-114.

Suciu, G et al (2013). Cloud computing as evolution of distributed computing: A case study for Slapos distributed cloud computing platform. Inf. Econ., 17(4), 109-122.

Suman \& Singh, P. (2016). Cloud computing in libraries: An overview International Journal of Digital Library Services, 6(1), 121-127.

Swapna, G. and Biradar, B.S (2017). Application of cloud computing technology in libraries. International Journal of Library and Information Studies, 7(1), 52.

U.S Census Bureau (2014). International Data Base Country Ranking (online) http://www.census.gov/population/international/data/idb/rank.php. 
Wada, I. (2018). Cloud computing implementation in libraries: A synergy for library services operation. International Journal of Library and Information Science, 10(2), pp 17-27.

Yuvaraj, M. (2013). An empirical study of implications of cloud computing applications in libraries using diffusion of innovation theory: determining factors of adoption. Pearl: A Journal of Library and Information Science 7(4), 191-199.

Yuvaraj, M. (2013). Cloud computing application in India Central University Libraries: A study of librarians use. Library Philosophy and Practice (E-journal), (992) Retrieved from http://digitalcommons.uni/liphilprac/992/ 